\title{
Przywrócenie wystroju zabytkowego wnętrza w gabinecie w wieży na zamku w Łańcucie
}

\section{Restoration of the interior decoration of the cabinet in the tower at the castle in Łańcut}

\section{Streszczenie}

Artykuł przybliża tematykę rekonstrukcji elementów wystroju wnętrza Gabinetu w wieży południowo-wschodniej, znajdującego się w Muzeum-Zamku w Łańcucie. Głównym celem jest prezentacja przeprowadzonych badań historycznych oraz problematyki związanej z badaniami historycznymi. W trakcie prowadzonych w latach 2014-2015 prac badawczych i konserwatorskich zostały zdiagnozowane oraz zrekonstruowane liczne elementy wystroju, tj. obrazy, grafiki, makaty, umeblowanie. Ponadto została też zbadana wcześniejsza dekoracja malarska, znajdująca się w zasłoniętej późniejszym stropem kopule. Na podstawie badań in situ oraz przeanalizowanej literatury przeprowadzono prace konserwatorskie oraz częściową rekonstrukcję elementów wystroju wnętrza.

Słowa kluczowe: malarstwo, konserwacja zabytków, historia architektury, ochrona dziedzictwa kulturowego

\begin{abstract}
This article covers the subject of reconstruction of the interior design elements of the Office in the tower, which is found on the south eastern side of the Museum-Castle in Lancut. Its main goal is to showcase the historical research that has been done, as well as, the problems entailed in the historical researches. Over the course of the research and conservation works carried out during the years 2014-2015, several elements have been recognized and reconstructed, which consist of: paintings, graphics, tapestries, and furniture. Furthermore, the earlier painted decorations which were found hidden above the ceiling copula, had also been analysed. On the basis of the research done in the original location, as well as the analysis of the relevant literature, covservation work was undertaken and partial reconstruction of the interior elements was performed.
\end{abstract}

Keywords: painting, preservation of monuments, history of architecture, protection of cultural heritage 


\section{WSTĘP}

Zamek w Łańcucie położony jest w obecnym województwie podkarpackim na skrzyżowaniu dawnych historycznych traktów komunikacyjnych łączących Kraków, Lwów i Leżajsk. Pierwszy łaciński zapis, mówiący o powstaniu ufortyfikowanego zamku w 1641 roku, znajduje się nad bramą główną: „Stanisław hrabia na Wiśniczu Lubomirski wojewoda, starosta generalny krakowski, zatorski, spiski, niepołomski, naczelny wódz wojsk Królewskich przeciw Osmanowi cesarzowi Turków Dzianumbet Girejowi chanowi Tatarów, aby odpocznienie zgotować siłom swoim staraniem o dobro publiczne, a także wojnami: inflandzką, moskiewską, pruską, scytyjską, turecką wreszcie samym wielkim steranych, budowlę tę wzniósł i ozdobił. Ażeby zaś pożytkowi wspólnemu mogła służyć, twierdzę dołączył Roku Chrystusowego $1641^{\prime \prime}$ (sic!). W późniejszym czasie zamek przechodził wiele przemian funkcjonalnych oraz liczne remonty i rozbudowy. Okres największych zmian to moment, kiedy majątkiem zarządza marszałek koronny Stanisław Lubomirski wraz z małżonką Izabellą z Czartoryskich w latach 1766-1816. Nastąpiły wtedy najdynamiczniejsze przebudowy, mające na celu zmodernizowanie zamku i jego przekształcenie na rezydencję. Jednym z pomieszczeń, które zostało całkowicie zmienione był Gabinet w wieży.

\section{GABINET W WIEŻY POŁUDNIOWO-WSCHODNIEJ}

Pomieszczenie, zlokalizowane w narożniku skrzydła wschodniego, wybudowane na planie ośmioboku, znajdujące się na poziomie pierwszego piętra wieży południowo-wschodniej, sąsiaduje z Salą Kolumnową i Pokojem Werandowym (il. 1). Dekorację ścian stanowi malarstwo płycinowe z niebieskim tłem, motywem groteski, utrzymanym w kolorach błękitnym i szarym oraz z bordiurą z liści dębu. Ściany zwieńczone zostały fasetą z motywem liści akantu. Salę przykrywa ośmioboczny płaski sufit o drewnianej konstrukcji z malarską dekoracją analogiczną do zdobień ścian. W północno-zachodnim murze zlokalizowane zostały drzwi do Sali Kolumnowej, które pokryte są malowidłami identycznymi z dekoracją ścian i sufitu, tworząc ukryte przejście. Obecnie we wschodnim murze znajduje się jedyne okno, w ścianie południowej przeszklone dwuskrzydłowe podwójne drzwi z nadświetlem, prowadzące na zadaszony balkon, natomiast w ścianie zachodniej przeszklone dwuskrzydłowe drzwi z nadświetlem, łączące pomieszczenie z Pokojem Werandowym. Posadzka sali została wykonana z dębu, orzecha, mahoniu i jawora w latach 30. XIX wieku według projektu Karola Chodzińskiego. Bogato intarsjowany wzór przedstawia motywy roślinne, a w jego centralnej części znajduje się rozeta, która podkreśla główną oś pomieszczenia. Na ścianie południowo-wschodniej umieszczony jest kominek z białego marmuru z malowanymi dekoracjami w stylistyce pompejańskiej (il. 2). Głębokie, ukośne glify okienne i drzwiowe (z wyjątkiem drzwi prowadzących do Sali Kolumnowej) pokryte są drewnianą malowaną 
boazerią płycinową. Do 1944 roku na ścianach znajdowały się wmurowane obrazy i sztychy przedstawiające Stanze Watykańskie, prezentujące freski Rafaela, wykonane przez Giovanniego Volpato na podstawie rysunków Stefano Tofanelli, a w poziomie sufitu, w centralnej części pomieszczenia, portret Henryka Lubomirskiego jako Serafina, autorstwa Marii Louise Cosway z 1787 roku² (il. 4). Do 2016 roku przez otwór w suficie można było dostrzec świadka starszego wystroju pomieszczenia w postaci kopuły z rokokową polichromią (il. 5). Starsze pomieszczenie, z którego zachowała się kopuła, posiadało cztery otwory okienne na ścianach północnej, południowej, zachodniej i wciąż istniejące na ścianie wschodniej oraz kręconą klatkę schodową w miejscu obecnie znajdującego się kominka, co potwierdza plan I piętra zamku sprzed 1780 roku (tzw. plan Patka). Okno północne zostało zamurowane już w 1802 roku $^{3}$, natomiast okno południowe zostało przekształcone na początku XIX wieku na przeszklone drzwi prowadzące na mały balkonik, co jest widoczne na akwareli z około 1829 roku autorstwa Willibalda Richtera ${ }^{4}$ (il. 3), która znajduje się w zbiorach Biblioteki Jagiellońskiej w Krakowie. Okno zachodnie przebudowano na drzwi do Pokoju Werandowego. Wówczas też powstał taras od strony południowej zamku, do którego obecnie prowadzą przeszklone drzwi na ścianie południowej. Na podstawie inwentarza z lat 1854-1855 można przypuszczać, że okno zachodnie przebudowano na drzwi balkonowe już w połowie XIX wieku i wówczas wychodziły one na balkon z zadaszeniem krytym blachą i otoczony żelazną galerią o szklanych ścianach5 ${ }^{5}$ Balkon znajdował się w miejscu dzisiejszego Pokoju Werandowego. Powstanie dekoracji malarskich autorstwa Lucjana Smuglewicza ${ }^{6}$ datuje się na ostatnie dziesięciolecie XVIII wieku. Był to okres przekształceń zamku za czasów ostatnich Lubomirskich - marszałka koronnego Stanisława Lubomirskiego i jego małżonki Izabelli z Czartoryskich. Najprawdopodobniej powyższe przekształcenia były skutkiem zagranicznej podróży Izabelli, która, zafascynowana nowinkami w dziedzinie dekoracji wnętrz, postanowiła zmodernizować zamek. Dekoracje klasycystyczne pomieszczeń, które objęto pracami (w tym także w Gabinecie w wieży), zostały utrzymane w tzw. stylu Adamów, który ukształtował się w drugiej połowie XVIII wieku w Wielkiej Brytanii, a następnie stał się popularny w niemal całej Europie i Stanach Zjednoczonych. Dekoracja z motywem rocaille i girland kwiatowych w kopule, widoczna przez otwór w suficie, najprawdopodobniej pochodzi z lat 60. XVIII wie$\mathrm{ku}^{7}$. Ze względu na cenną polichromię, znajdującą się na ścianach, w trakcie wykonywanych badań konserwatorsko-architektonicznych pomieszczenia w 2015 roku nie udało się określić, czy istniała również wcześniejsza rokokowa dekoracja ścian. Istnieją również przesłanki, że pod dzisiejszym malowidłem znajduje się jeszcze starsza dekoracja pomieszczenia, która mogłaby powstać w momencie wzniesienia baszty, czyli w XVII wieku ${ }^{8}$. Klasycystyczne polichromie pomieszczenia, które można podziwiać obecnie, najprawdopodobniej powstały po 1780 roku, czyli w momencie przekształcenia pomieszczenia przez Izabellę Czartoryską. Istnieje duże prawdopodobieństwo, że powstały po 1783 roku, w momencie, w którym Henryk Lubomirski został mieszkańcem zamku, lub też kilka lat później, w 1787 roku. Powstał wtedy portret Henryka jako Serafina, autorstwa Marii Louise Cosway, do którego wykonano płaski 
sufit przysłaniający kopułę. Dekoracja malarska ścian dopasowana jest do rycin i obrazów, które znajdowały się w gabinecie do 1944 roku.

W 1944 roku Alfred Potocki wywiózł z zamku za granicę 11 wagonów najcenniejszych dzieł sztuki oraz elementy wyposażenia wnętrz, w tym obrazy znajdujące się w Gabinecie w wieży ${ }^{9}$. Od tego momentu opisywane $w$ artykule pomieszczenie nie było remontowane ani konserwowane. W trakcie prac konserwatorskich, prowadzonych przez zespół firm Art Forum i Konserwacja Zabytków Sabina Szkodlarska, wykonano wnikliwe badania, mające na celu między innymi odnalezienie i zdiagnozowanie elementów wystroju pomieszczenia. Wnioski z niniejszych badań oraz rozwarstwienie stratygraficzne zostały przedstawione w Dokumentacji powykonawczej z prac konserwatorskich, badawczych i rekonstrukcyjnych w Gabinecie w wieży południowo-wschodniej na I piętrze w Muzeum-Zamku w Łańcucie z 2016 roku$^{10}$.

\section{PRZEBIEG I ZAKRES BADAŃ ARCHITEKTONICZNYCH ORAZ KONSERWATORSKICH ${ }^{11}$}

Badania stratygraficzno-odkrywkowe na ścianach wykazały, że pokryte były one jedenastoma warstwami technologicznymi z VI faz chronologicznych. Po dokładnej analizie, zarówno stylistycznej, jak i chemicznej, potwierdzono, że poszczególne partie malowideł różnią się od siebie. Partie płycinowe przedstawiają malarstwo iluzjonistyczne, natomiast ornament z liści dębu na bordiurze wykonany jest metodą patronową. W miejscach ubytków warstwy malarskiej widoczna była warstwa wcześniejszej polichromii, natomiast obecnie widoczna bordiura jest jej powtórzeniem z lekkim przesunięciem wzoru (najprawdopodobniej po 1911 roku). Niewielkie różnice $w$ formie polichromii występowały w głębokich ościeżach i na drzwiach prowadzących do Sali Kolumnowej. W dolnych partiach ścian południowo-zachodniej i południowo-wschodniej widoczne były ślady wcześniejszych miejscowych przemalowań oryginalnej warstwy malarskiej.

Przeprowadzone badania pozwoliły ustalić, że istniejąca w 2015 roku polichromia, będąca VI warstwą chronologiczną, stanowiła przemalowanie wcześniejszego, oryginalnego malowidła z końca XVIII wieku - III warstwa chronologiczna. Początkowe przypuszczenia, że bordiura z liści dębu powstała później, ze względu na jej bardziej schematyczną formę w porównaniu z iluzjonistyczną dekoracją malowanych płycin, zostały rozwiane podczas badań. Przypuszczenia te zweryfikowały również badania stylistyczne i historyczne dekoracji, które pozwoliły na odnalezienie analogii dla bordiury w dekoracji antycznego Złotego Domu Nerona, który został odkryty w drugiej połowie XVIII wieku. Jego wystrój stał się inspiracją dla wielu klasycystycznych wnętrz, powstających pod koniec XVIII wieku. Reprodukcje malowideł antycznych, rozpowszechniane w formie wzorników, były znane księżnej Izabelli Czartoryskiej, która współpracowała z wieloma artystami pracującymi podczas prac odkrywkowych w willi. Badania konserwatorskie wykazały również istnienie kolejnych dwóch warstw 
wcześniejszych polichromii (IV, V warstwa chronologiczna), które zlokalizowano jedynie miejscowo na ścianie południowo-zachodniej i południowo-wschodniej. Przemalowania te najprawdopodobniej powstały $w$ trakcie prac renowacyjnych w pomieszczeniu i miały na celu pokrywać ubytki, które powstały w skutek użytkowania pomieszczenia, przesuwania mebli we wnętrzu.

Il warstwę chronologiczną, odkrytą na ścianach, należy utożsamiać z wcześniejszą dekoracją pomieszczenia w stylu rokokowym. Odkryte ślady ciemnobrązowych pasków nawiązują do iluzjonistycznie malowanych żeber, widocznych na zachowanej dekoracji wnętrza kopuły. Dekoracje z motywem muszli i rocaille reprezentują jeszcze początkową formę ornamentyki rokokowej, trudno jednak określić, jak szybko motywy te dotarły do Łańcuta. Sufit z desek w pomieszczeniu powstał pod koniec XVIII wieku, w momencie tworzenia nowego wystroju pomieszczenia w stylistyce pompejańskiej. Z tego względu nie odnaleziono pod warstwą malarską i zaprawą II warstwy chronologicznej dekoracji rokokowej.

\section{PRACE KONSERWATORSKIE I REKONSTRUKCJA WYPOSAŻENIA WNĘTRZA}

Decyzję o pełnej rekonstrukcji wystroju pomieszczenia w Gabinecie w wieży podjęto z uwagi na to, że muzeum mieszczące się w zamku posiada szczegółowy materiał ikonograficzny z lat 20. XX wieku autorstwa Józefa Piotrowskiego ${ }^{12}$. Zakresem prac objęto polichromię znajdującą się na ścianach, suficie i w kopule, konserwację intarsjowanej posadzki, rekonstrukcję obrazu olejnego oraz sztychów wraz z dekoracyjnymi ramami, zasłon i żardiniery. Sala na początku XIX wieku została przedstawiona na akwareli autorstwa Willibalda Richtera z 1829 roku. Widać na niej wyraźnie, że wszystkie obrazy i sztychy były kolorowe, a nie jak do tej pory uważano czarno-białe. W zbiorach archiwum Muzeum-Zamku w Łańcucie znajdowały się fotografie z około 1911 roku przedstawiające salę. Widać na nich dokładne rozmieszczenie poszczególnych obrazów i rycin, umeblowanie, w tym rekonstruowaną podczas prac żardinierę. Dodatkowo widoczna na fotografii zasłona była haftowana i inaczej drapowana niż na wyżej wymienionej akwareli. Po przeprowadzeniu kwerendy historycznej, której autorem była Wiktoria Kałwak, ustalono, że w gabinecie znajdował się cykl grafik przedstawiających freski Rafaela Santi w Stanzach Watykańskich, który datuje się na około 1780 rok. Niniejsze sztychy zostały wykonane w technice miedziorytu i akwaforty, dodatkowo zostały one podmalowane, najprawdopodobniej akwarelą. Autorstwo niniejszych prac przypisuje się Giovanniemu Volpato (miedzioryt) i Stefano Tofanelliemu (rysunek). Na ścianach przywrócono pierwotny układ rycin, które znajdowały się w czterech pustych niszach: Szkoła Ateńska, Parnas, Wygnanie Heliodora i Uwolnienie św. Piotra. Największy obraz, znajdujący się w centralnej części sufitu, przedstawiający Henryka Lubomirskiego jako amora, zrekonstruowano dzięki udostępnieniu wysokorozdzielczej fotografii przez prywatną właścicielkę mieszkającą w Rzymie (il. 6). W wyniku dalszych badań ustalono, że w pomieszczeniu znajdowały się jeszcze cztery grafiki 
w prostokątnych ramach, znajdujących się na suficie i jedna nad drzwiami do Sali Kolumnowej. Niniejsze dzieła wykonane zostały przez Angelo Campanella i Pietra Marco Vitaliego na podstawie rysunków Antona Raphaela Mengsa i Antona von Marona. Obrazy przedstawiały wnętrze z dekoracją ze scenami mitologicznymi w Villi Negroni w Rzymie. Diagnoza grafik znajdujących się w czterech okrągłych ramach na suficie okazała się znacznie trudniejsza od opisanych powyżej. Na materiale ikonograficznym odczytanie zawartości obrazów było niemożliwe. Na fotografii z początku XX wieku, znajdującej się w zbiorach muzealnych, widoczny jest układ postaci znajdujących się w okrągłej grafice. Postać odzianej kobiety, przypominającej swym kształtem trytony, zidentyfikowano jako scenę rozmowy Glaukosa ze Scyllą. Pierwotne przedstawienie zostało odkryte około połowy XVIII wieku w Willi Hadriana w Tivoli. Zainspirowało ono Marco Carloniego do wykonania litografii w 1786 roku (il. 8).

Kolejnym istotnym elementem wystroju była drewniana żardiniera, która znajdowała się w jej centralnym punkcie. Z mebla zachowały się jedynie cztery nogi, a pozostałe elementy trzeba było zrekonstruować. Na fotografii z 1911 roku i późniejszej z lat 20. XX wieku widoczna jest trójpoziomowa żardiniera z umieszczoną w XX wieku w szczycie lampą oświetlającą portret Henryka. Nie zachowały się również zasłony, które widoczne są na fotografii. Z tego powodu podjęto decyzję o rekonstrukcji w oparciu o analogię. Ponieważ na wyżej wymienionych źródłach istnieją różne tkaniny, należało wybrać jedną, najbardziej pasującą do pomieszczenia. Wybrano makatę widoczną na fotografii, ponieważ niniejsze źródło posiadało najwięcej informacji dotyczących szczegółów. Metodami cyfrowymi opracowano udostępnioną fotografię w celu uszczegółowienia motywu wyhaftowanego motywu. Ponieważ tkanina na fotografii jest mocno udrapowana, nie udało się wykonać pełnej rekonstrukcji wzoru. W tym celu wykonano kwerendę w poszukiwaniu analogii. Udało się odnaleźć tkaninę, której wzór jest niemal identyczny z widocznym na fotografii. Tkanina widniejąca na zdjęciu została wykonana z makaty tureckiej, rozdzielonej na trzy elementy, dwa z nich powieszono po obu stronach okna, trzeci fragment użyto jako lambrekin i zawieszono go w poprzek. Analogia, która posłużyła do opracowania rekonstruowanego wzoru, znajduje się w kolekcji Kulczyckich w zbiorach Zamku Królewskiego na Wawelu. Opracowany cyfrowo wzór został wydrukowany na ciemnoczerwonej satynie bawełnianej drukiem cyfrowym, wielkoformatowym, w technice UV farbą światło utwardzalną (il. 7).

\section{PODSUMOWANIE}

Dzięki współpracy zarówno badaczy, grafików, wykonawców prac, jak i inwestora ${ }^{13}$ udało się uzyskać najwierniejszy obraz wnętrza z epoki. Ze względu na lokalizację i małą powierzchnię pomieszczenia nie jest ono dostępne dla zwiedzających. Jednak dzięki opracowanej dokumentacji istnieje możliwość pokazania sali gościom zamku. 


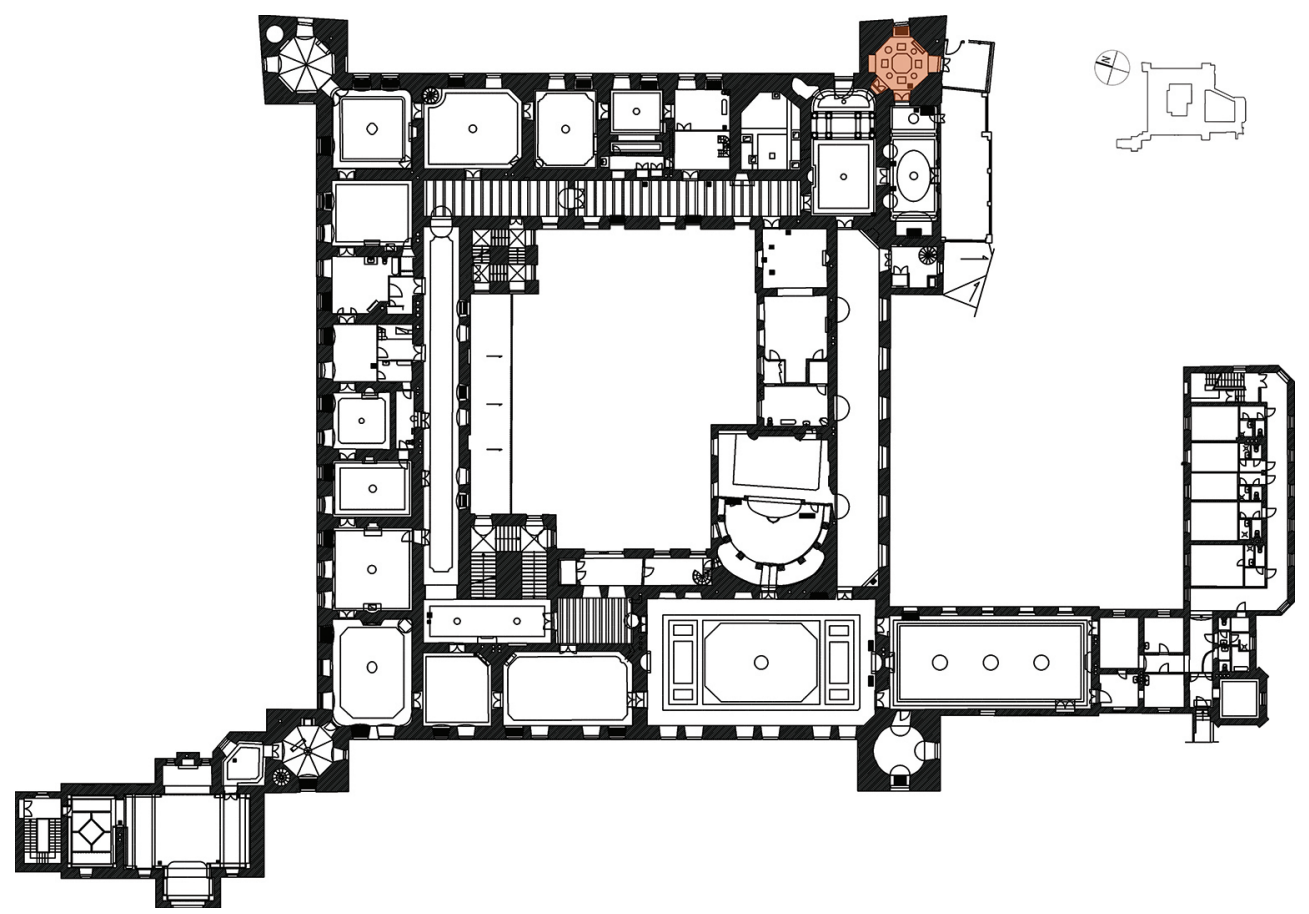

II. 1. Gabinet w wieży, rzut I piętra Zamku z zaznaczeniem lokalizacji omawianego wnętrza (ryc. P. Łyziak-Dyga na podstawie materiałów opracowanych przez firmę Nizio Design International, 2015) III. 1. Cabinet in the tower, projection of the 1st floor of the Castle with the marked location of the discussed interior (fig. P. Łyziak-Dyga based on materials developed by Nizio Design International, 2015) 


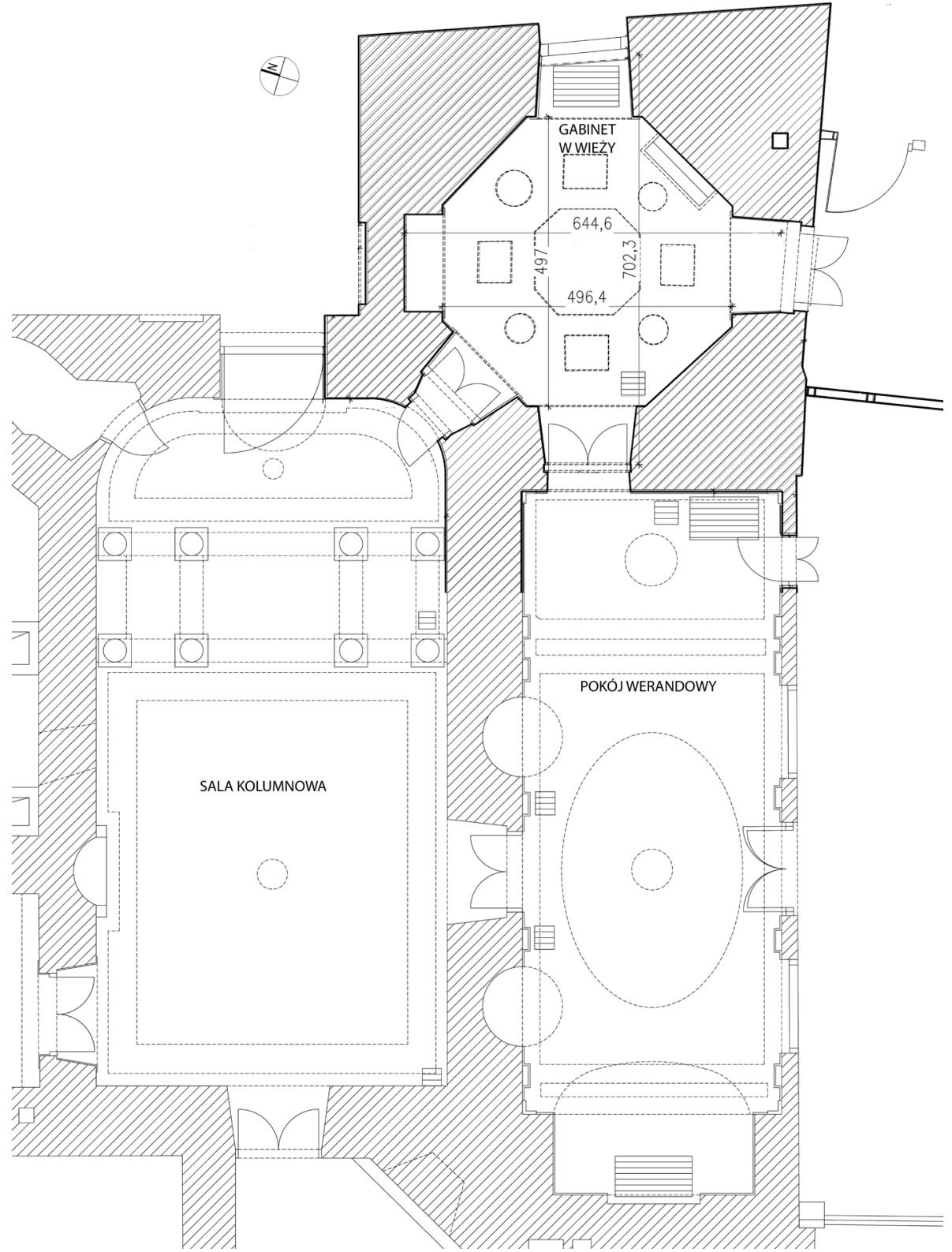

II. 2. Gabinet w wieży, rzut pomieszczenia (ryc. P. Łyziak-Dyga na podstawie materiałów opracowanych przez firmę Nizio Design International, 2015)

III. 2. Cabinet in the tower, projection of the interior (fig. P. Łyziak-Dyga based on materials developed by Nizio Design International, 2015) 


\section{BADANIA KONSERWATORSKIE \\ Badania stratygraficzno-odkrywkowe}

\begin{tabular}{|c|c|c|c|c|}
\hline $\begin{array}{c}\text { Warstwy } \\
\text { technologi- } \\
\text { czne }\end{array}$ & $\begin{array}{c}\text { Faza } \\
\text { chronologi- } \\
\text { czna }\end{array}$ & Datowanie & Ściany i sufit & Elementy wystroju \\
\hline 1 & VI & po 1911 r. & $\begin{array}{l}\text { Warstwa malarska- } \\
\text { przemalowania teł } \\
\text { i bordiur na ścianach } \\
\text { (bez sufitu) }\end{array}$ & $\begin{array}{l}\text { Drzwi do Sali Kolumnowej (od } \\
\text { wewnątrz miejscowe } \\
\text { przemalowanie polichromii } \\
\text { pompejańskiej, od zewnątrz szara } \\
\text { monochromia) } \\
\text { Drzwi na taras przeszklone } \\
\text { (monochromia) }\end{array}$ \\
\hline 2 & VI & po 1911 r. & $\begin{array}{l}\text { Kity wapienno- } \\
\text { piaskowe }\end{array}$ & \\
\hline 3 & $\mathrm{~V}$ & $\begin{array}{l}\text { 1890-95 } \\
\text { powstanie } \\
\text { Pokoju } \\
\text { Werando- } \\
\text { wego }\end{array}$ & $\begin{array}{l}\text { Przemalowanie } \\
\text { miejscowe w obrębie } \\
\text { dolnej części ściany } \\
\text { południowo-zachodniej }\end{array}$ & $\begin{array}{l}\text { Powstanie drzwi na taras, do } \\
\text { Pokoju Werandowego, okna } \\
\text { i boazerii drewnianej (trójpodział } \\
\text { kolorystyczny - różowy, biały, } \\
\text { szary) } \\
\text { Dwuskrzydłowe } \\
\text { i jednoskrzydlowe drzwi do Sali } \\
\text { Kolumnowej } \\
\text { (monochromia szara) }\end{array}$ \\
\hline 4 & IV & $\begin{array}{l}1 \text { pol. XIX } \\
\text { w. }\end{array}$ & $\begin{array}{l}\text { Przemalowanie } \\
\text { miejscowe w obrębie } \\
\text { dolnej części ściany } \\
\text { południowo-zachodniej } \\
\text { i dolnej części ściany } \\
\text { południowo-wschodniej }\end{array}$ & $\begin{array}{l}\text { Dwuskrzydłowe } \\
\text { i jednoskrzydłowe drzwi do Sali } \\
\text { Kolumnowej (monochromie szare } \\
\text { od wnętrza korytarzyka) }\end{array}$ \\
\hline 5 & IV & $\begin{array}{l}1 \text { pol. XIX } \\
\text { w. }\end{array}$ & $\begin{array}{l}\text { Kity wapienno- } \\
\text { piaskowe }\end{array}$ & $\begin{array}{l}\mathbf{1 8 3 0} \text { r. - powstanie parkietu } \\
\text { intarsjowanego autorstwa } \\
\text { Chodzińskiego }\end{array}$ \\
\hline 6 & III & Ok. 1780 & $\begin{array}{l}\text { Warstwa malarska - } \\
\text { polichromia } \\
\text { pompejańska }\end{array}$ & $\begin{array}{l}\text { Dwuskrzydlowe drzwi do Sali } \\
\text { Kolumnowej (od wewnątrz } \\
\text { polichromia pompejańska, od } \\
\text { zewnątrz fladrowanie) }\end{array}$ \\
\hline 7 & III & Ok. 1780 & $\begin{array}{l}\text { Zaprawa wapienno- } \\
\text {-piaskowa }\end{array}$ & $\begin{array}{l}\text { Powstanie jednoskrzydlowych } \\
\text { drzwi do Sali Kolumnowej } \\
\text { (fladrowanie od wnętrza } \\
\text { korytarzyka) }\end{array}$ \\
\hline 8 & III & Ok. 1780 & $\begin{array}{l}\text { Drewno (deski i belki } \\
\text { sufitu) }\end{array}$ & $\begin{array}{l}\text { Powstanie marmurowego } \\
\text { kominka }\end{array}$ \\
\hline 9 & II & Ok. 1750 & $\begin{array}{l}\text { Warstwa malarska paski } \\
\text { ciemnobrązowe, } \\
\text { zachowana polichromia } \\
\text { w kopule }\end{array}$ & $\begin{array}{l}\text { Dwuskrzydłowe drzwi do Sali } \\
\text { Kolumnowej (polichromia } \\
\text { rokokowa) } \\
\text { Powstanie parkietu w tafle (?) }\end{array}$ \\
\hline 10 & II & Ok. 1750 & $\begin{array}{l}\text { Zaprawa wapienno- } \\
\text {-piaskowa }\end{array}$ & \\
\hline 11 & $\mathrm{I}$ & $\begin{array}{l}\text { XVII w. - } \\
\text { moment } \\
\text { powstania } \\
\text { Zamku }\end{array}$ & $\begin{array}{l}\text { Wątek kamienno- } \\
\text {-ceglany }\end{array}$ & \\
\hline
\end{tabular}

II. 3. Gabinet w wieży, tabela stratygraficzna pokazująca rozwarstwienie historyczne wnętrza

(ryc. B. Boba-Dyga, S. Szkodlarska, 2015)

III. 3. Cabinet in the tower, a stratigraphic table presenting the historical stratification of the interior 


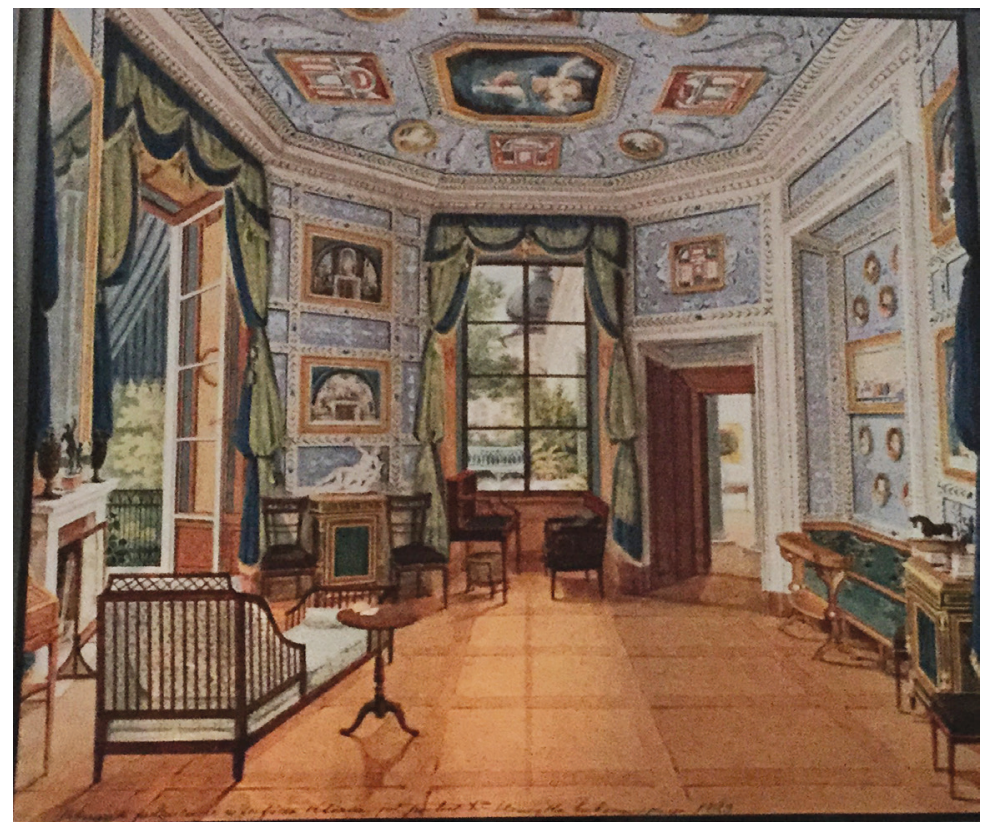

II. 4. Gabinet w wieży, akwarela autorstwa Willibalda Richtera (fot. B. Boba-Dyga, 2015)

III. 4. Cabinet in the tower, watercolour by Willibald Richter

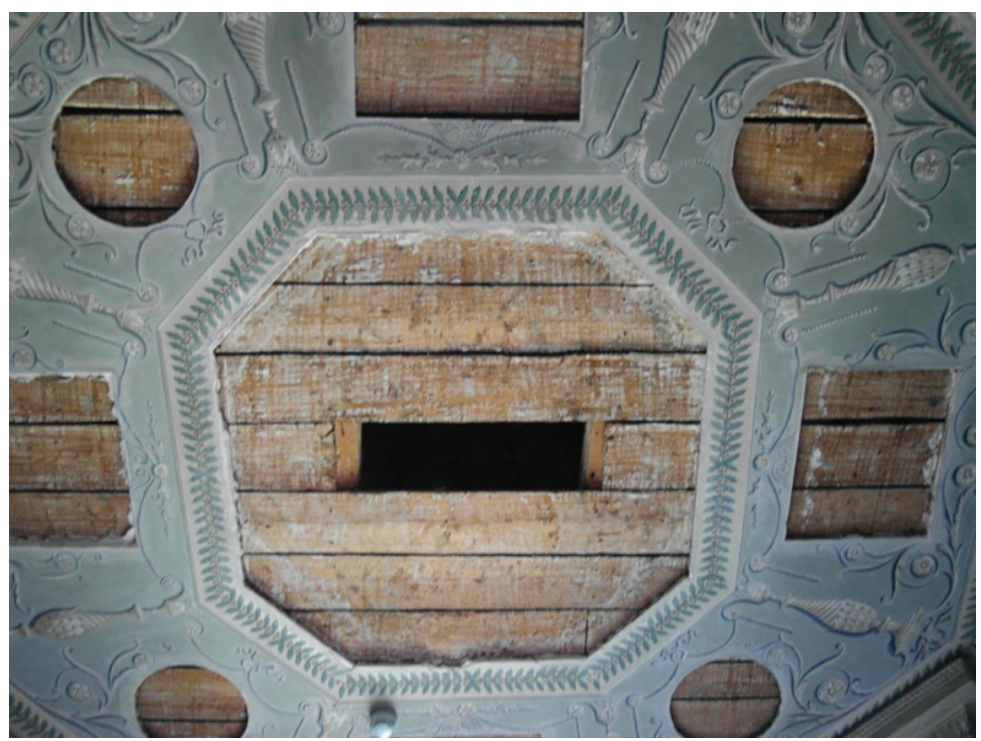

II. 5. Gabinet w wieży, sufit pomieszczenia przed rozpoczęciem prac (fot. K. Szkodlarska, 2015) III. 5. Cabinet in the tower, the ceiling of the room before commencing works 


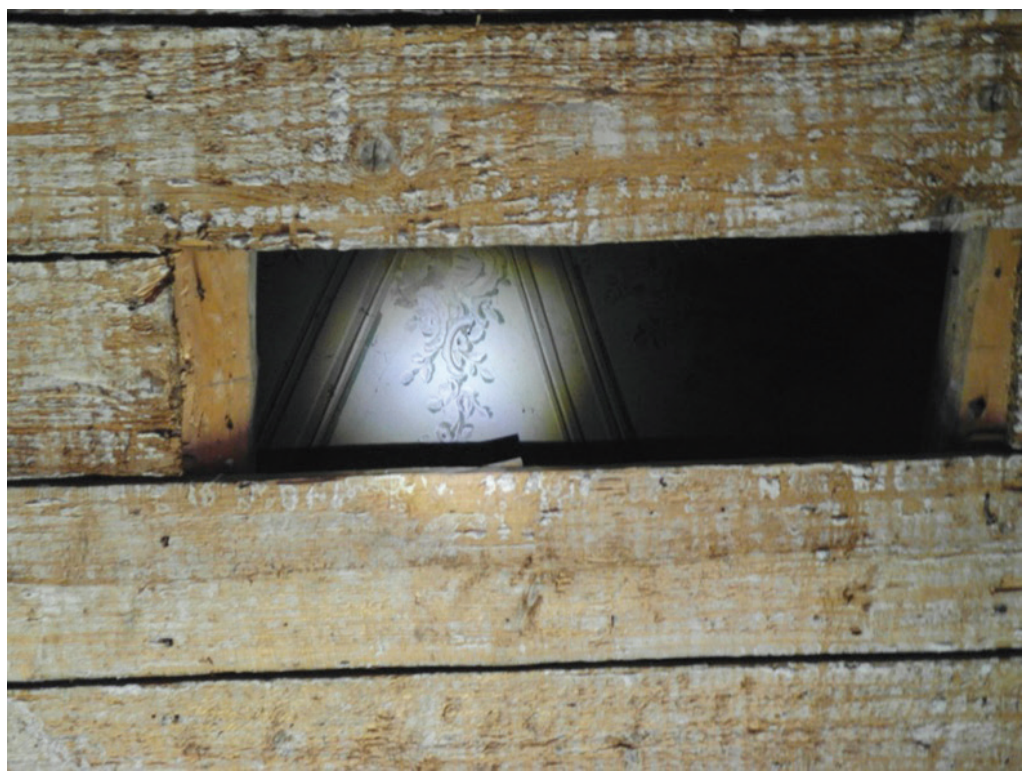

II. 6. Gabinet w wieży, widoczna polichromia znajdująca się w kopule (fot. K. Szkodlarska, 2015) III. 6. Cabinet in the tower, polychromy visible in the dome

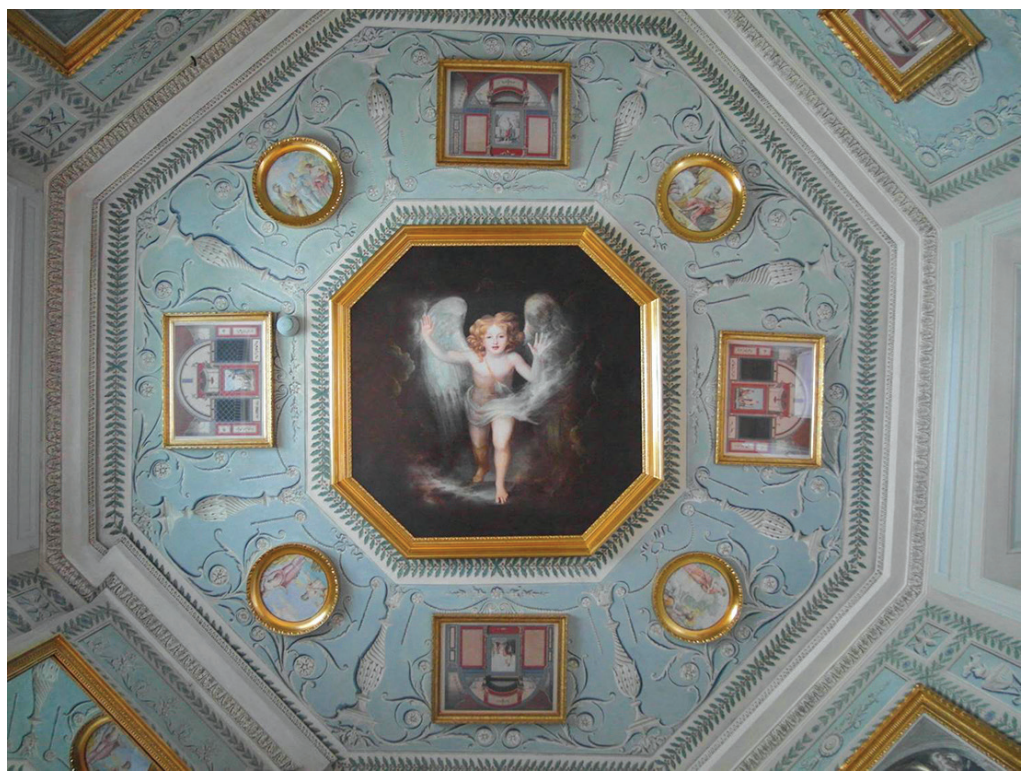

II. 7. Gabinet w wieży, sufit po przeprowadzonych pracach (fot. K. Szkodlarska, 2015) III. 7. Cabinet in the tower, the ceiling of the room after works carried out 


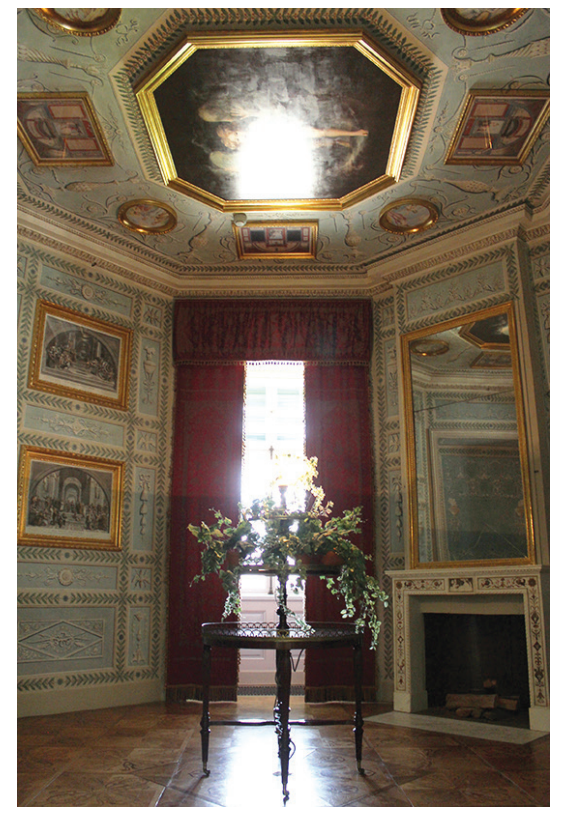

II. 8. Gabinet w wieży ze zrekonstruowanym wyposażeniem (fot. P. Łyziak-Dyga, 2015)

III. 8. Cabinet in the tower with the reconstructed equipment

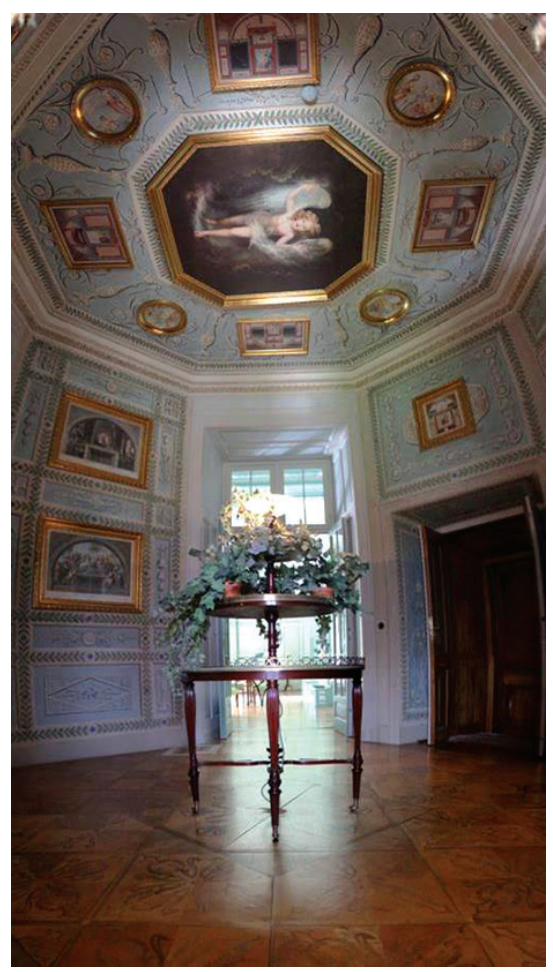

II. 9. Gabinet w wieży ze zrekonstruowanym wyposażeniem (fot. P. Łyziak-Dyga, 2015)

III. 9. Cabinet in the tower with the reconstructed equipment 


\section{PRZYPISY}

1 J. Bogdanowski, Fortyfikacje łańcuckie na tle małopolskiej sztuki obronnej, Muzeum-Zamek w Łańcucie, Łańcut 1976, s. 9-10. Napis łaciński na tablicy erekcyjnej brzmi: „Stanislus Comes in Wisnicz Lubomirski palatinus et generalis crac(oviensis) Zatorien(sis) Scepvien(sis) Nepolomice $\mathrm{N}(\mathrm{sis}) \mathrm{E}(\mathrm{t}) \mathrm{c}$ (etera) Capitaneus exercitvum regni. Contra osmanv $(\mathrm{m})$ imperatore $(\mathrm{m})$ turcaru(m) Et Dzianumbet Gerej chanum tartarorum generalis praefectus et virib(us), curis pub(li)(cis) atq(ue) bellis livonico Moschino prussio scythico, Turcico ipsa domv(m) Aetate Fessis qvietem pararet. Aedes has condidit et ornavit ut salvti com(m)uni prodesset: propugnaculu(m)adiecit an(n)o Christi, MDCXLI".

2 M. Omilanowska, J. Sito, Katalog Zabytków Sztuki w Polsce. Seria nowa, T. III: Województwo rzeszowskie, z. 5: Łańcut i okolice, Instytut Sztuki PAN, Warszawa 1994, s. 40-41.

3 Z. Kossakowska-Szanajca, B. Majewska-Maszkowska, Zamek w Łańcucie, Arkady, Warszawa 1964, s. 215-218.

4 B. Majewska-Maszkowska, Mecenat artystyczny Izabelli z Czartoryskich Lubomirskiej 17361816, Instytut Sztuki PAN, Wrocław-Warszawa-Kraków 1976, s. 270.

5 Z. Kossakowska-Szanajca, B. Majewska-Maszkowska, op. cit., s. 215-218.

6 M. Omilanowska, J. Sito, op. cit., s. 40.

7 Ibidem.

8 Niniejsze przypuszczenie może potwierdzać zachowana polichromia znajdująca się w kopule, która będzie w przyszłości badana.

9 J. Kieszkowska-Kotzowa, Prace remontowo-konserwatorskie w zamku łańcuckim, „Ochrona Zabytków", 12/3-4, 1959, s. 369.

10 B. Boba-Dyga, S. Szkodlarska, W. Kałwak, Dokumentacja powykonawcza z prac konserwatorskich, badawczych i rekonstrukcyjnych w Gabinecie w wieży południowo-wschodniej na I piętrze w Muzeum-Zamku w Łańcucie w ramach projektu „Kompleksowe prace konserwatorskie wystroju zabytkowych wnętrz (ściany, sufity, stolarka okienna z żaluzjami, stolarka drzwiowa, posadzki oraz kominki) wszystkich pomieszczeń na Il piętrze i wybranych pomieszczeń na I piętrze" - zadanie pt. Konserwacja wnętrz Gabinetu w wieży płd.-wsch., Pokoju Werandowego i Apartamentu Chińskiego, mps, Kraków 2016.

11 Ibidem, s. 83-97.

12 Albumy fotografii znajdują się w Archiwum Muzeum-Zamku w Łańcucie oraz w Archiwum Państwowego Instytutu Sztuki przy Polskiej Akademii Nauk w Warszawie.

${ }^{13}$ Inwestorem prac było Muzeum-Zamek w Łańcucie, wykonawcą prac i opracowań badawczych był zespół konsorcjum firm: Art Forum Bożena Boba-Dyga i Konserwacja Zabytków Sabina Szkodlarska; w składzie zespołu pracowała Kaja Szkodlarska - kierownik prac konserwatorskich, Wiktoria Kałwak - kwerenda archiwalna, Paulina Łyziak-Dyga - inwentaryzacja konserwatorska i dokumentacja, Wojciech Szkodlarski - opracowania graficzne; prace wykonano w 2015 r. Pewne elementy, takie jak rokokowa polichromia, ze względów technologicznych nie zostały zbadane - będą one stanowiły wyzwanie dla kolejnych badaczy. 


\section{BIBLIOGRAFIA}

Bogdanowski J., Fortyfikacje łańcuckie na tle małopolskiej sztuki obronnej, Łańcut 1976.

Kieszkowska-Kotzowa J., Prace remontowo-konserwatorskie w zamku łańcuckim, „Ochrona Zabytków", 12/3-4, Warszawa 1959.

Kossakowska-Szanajca Z., Majewska-Maszkowska B., Zamek w Łańcucie, Warszawa 1964.

Majewska-Maszkowska B., Mecenat artystyczny Izabelli z Czartoryskich Lubomirskiej 17361816, Wrocław-Warszawa-Kraków 1976.

Omilanowska M., Sito J., Katalog Zabytków Sztuki w Polsce. Seria nowa, T. III: Województwo rzeszowskie, z. 5: Łańcut i okolice, Warszawa 1994. 